AperTO - Archivio Istituzionale Open Access dell'Università di Torino

\title{
Missing HRM: the original sin of museum reforms in Italy
}

\section{This is a pre print version of the following article:}

Original Citation:

\section{Availability:}

This version is available http://hdl.handle.net/2318/1689417

since 2020-02-19T12:23:23Z

Published version:

DOI:10.1080/09647775.2018.1537608

Terms of use:

Open Access

Anyone can freely access the full text of works made available as "Open Access". Works made available under a Creative Commons license can be used according to the terms and conditions of said license. Use of all other works requires consent of the right holder (author or publisher) if not exempted from copyright protection by the applicable law. 


\title{
Missing HRM: the original sin of museum reforms in Italy
}

\author{
Luca Zan*, Sara Bonini Baraldi** and Maria Elena Santagati* \\ *Department of Management, University of Bologna; **Interuniversity Department of Regional and \\ Urban Studies and Planning, University of Turin and Polytechnic School of Turin
}

\begin{abstract}
The Italian Ministry of Culture has been undertaking substantial reforms in the last decades, aimed at reorganizing both the museum sector and the local branches of the Ministry, the Superintendence system. By reconstructing the genealogy of these reforms from a management study perspective, the paper points out the overall misunderstanding of human resource issues in their design and implementation. Starting from the Pompeii reform in 1997 up to the Franceschini reform in 2014-2016, the authors focus on the main inconsistencies, omissions and mistakes undermining the effectiveness of change processes. The 'original sin' of museum reforms in Italy, mainly due the predominance of a legislative approach and the lack of a management perspective by the ministerial apparatus and law makers, calls for a new approach in organizational and HR terms.
\end{abstract}

Keywords: museum reforms; HR management; legislative approach; management knowledge

\section{Introduction: a takeover in professional jurisdiction?}

The Italian national museum system is currently undergoing a reform with the alleged intent to radically change its structure and functioning. The reform is based on a number of new laws, decrees and regulations modifying the organizational structure, governance, accounting and financial rules of the ministerial bodies in charge of cultural heritage, and includes the selection of new directors through an international competition for 30 newly-autonomous museums. A large debate among professionals, researchers and politicians surrounds the reform, yet without adequately placing it in the historical context of previous reforms, along with their unsolved problems, contradictions and limits. ${ }^{1}$

\footnotetext{
${ }^{1}$ What is now the Ministry (MiBACT, Ministry of Cultural Goods and Activities, and Tourism) has been continuously reformed since it was created in 1975. Reconstructing the whole picture would require, if not deserve, an entire book. That reforms can be implemented effectively with such a rate of change - a total of 25 ministries in the period - is open to discussion.
} 
That Italy is a country dominated by law is not a new observation, despite years of debate. The impressive numbers of laws (said to be about 170.000) is simply unique in the world, even in other countries sharing the same traditions of civil law (Bonini Baraldi 2014; Pollitt and Bouckaert 2011; Kickert 2004; Panozzo 2000). More particularly, the (increasing) intrusion of administrative law in all aspects of public sector governance has reached unprecedented levels, requiring new projects of "administrative simplification" (Cassese, 1998), which often leave the impression of being even more complicated than the problems they try to solve. The heritage field - or more accurately the "cultural goods" (beni culturali) sector, in itself a specific legal construct in the Italian administrative tradition - is not an exception.

However, there is something peculiar about the heritage field in Italy, compared to the general process of administrative change taking place worldwide, often under the umbrella of the New Public Management movement (Hood 1991; Kickert 1997; Hood 1995a, 1995b; Barzelay 1992; 2001; Pollitt and Bouckaert 2011): the lack of understanding of organizational and managerial principles by Italian lawmakers. More explicitly, one could describe it as a process of professional takeover, wherein (Italian) lawyers occupy spaces normally occupied (in the rest of the world) by management experts. Most of public sector (and in specific cultural institutions) administrative directors have a background in law rather than management or accounting. Sometime their accounting knowledge is close to zero: in most legal programs there is just one course on economics, and usually nothing about management, accounting, costs, budgets, and human resources.

A decade's debate about the transformation of Italian opera houses demonstrates the possible consequences of dominance by the legalistic perspective (Sicca and Zan 2005). Rather than addressing the issue of a more focused division of labor amongst the fourteen opera houses to increase their efficiency, the law introduced incentives to increase the number of productions. Even more telling from our perspective, the law introduced a new construction, the board of directors, which was going to be in charge for four years. Unfortunately, the law was declared in June, so the boards of the fourteen opera house were (and still are) elected and changed with this periodization. Nobody noticed that in this way, the first and the last years would result in a financial report where nobody is responsible for the annual results and the respective financial reports (who was responsible? The new or the old board?). Even when this element emerged in the debate (Sicca and Zan 2005: 60), nothing really changed. Finally, in the case of Opera houses an interesting phenomenon emerges, what we refer to as "Italian Thatcherism" (61), whereby State subsidies are cut, even severely, without affecting human resources. In the case of the Teatro Comunale in Bologna, within ten years the State subsidies were reduced by $25 \%$ without significant increases of 
alternative funding: yet not a single employee was fired, nor the previous contracts changed. The risk is that organizations have scarce resources to spend creating quality activities, apart from paying salaries.

The above provides a very brief context for the international reader to understand the complex and often conflicted evolution of the reforms of Italian national (i.e. State run) museums.

\section{The original sin or the imprinting bias}

The basic assumption of this paper is that the shortcomings of the current reform are related to its initial imprinting: a process that was totally unable to learn from earlier mistakes and limitations from a managerial point of view. Unfortunately, this is a quite internally consistent evolution across the various steps of the reforms, which we will try to disentangle in the next section:

a. the continual debate prior to 1997 ;

b. the initial reform of Pompeii (law 1997), with major internal contradictions that were never solved;

c. the early enlargement of (part of) the Pompeii reform to include a few large museums, the socalled "Museum hubs" (Poli museali);

d. the tacit dismantlement of the Pompeii reform's innovations;

e. the initial innovation of the Franceschini reform, with the "20 Directors" selection, and subsequent changes.

In the whole process, the issue of human resources and the crucial issue of organization of labour are left behind. Sometimes these issues are seen as boring, bureaucratic consideration, in conflicting with the more academic content of the curator's job. ${ }^{2}$ Sometime the innovation introduced - as seen in the case of Pompeii in 1997 - the lack of innovation in terms of human resource management ends up with perverse mechanisms, as we will show. In all cases, one of the biggest surprises of the "new directors" was probably the realisation that they were not expected nor had the responsibility, powers and tools - to manage the staff of the museums. Their professional experience echoes that of the first "city manager" in Pompeii, who suddenly realized that his arrival was the only change in the whole organization of labour, and found he was not able to take his team and trusted collaborators with him.

\footnotetext{
${ }^{2}$ A typical position of the time is condensed in the following sentence: "They should be superintendents only for the archaeological objects, or even the historical and artistic ones ... or even more so the environmental and architectonic assets. Instead, they are also asked to motivate the employees, above all those which are extremely frustrated working in the offices, or to introduce minimal rules of 'business' behavior" (Dell'Orso, 2002: 79).
} 
Optimists may say that this is a gradual process, and things will change and improve in the future. Our view is more disenchanted: nothing improved in the past two decades. The Pompeii reform itself was set up explicitly as an "experiment", but nothing really was done to improve the experiment and resolve its intrinsic limitations and contradictions, and all the weakness of the original law continued to affect the extension of the "innovation" to the museum hubs and further reforms.

\section{Reconstructing the genealogy of reforms from a management study perspective}

In this section we will revisit the various steps inside the lawmaking process in the Italian national museums and local branches of the Ministry, in order to support our critique of the lack of managerial understanding.

\section{a) The debate prior to 1997}

The Italian cultural heritage system has traditionally been based on a strictly centralized and hierarchical model (D’Alessio, 1992; Bobbio, 1992). Within this model, the Ministry for Cultural Heritage is responsible for protection on all national heritage (both public and private property) and for the direct management of all state-owned cultural assets (including the most important archaeological sites and museums such as Pompeii, the Uffizi and the Gallerie dell'Accademia in Venice and the Pinacoteca di Brera in Milan) through a capillary set of local branches of the Ministry called Superintendencies. The Superintendencies were divided by sector (one for archaeology, fine arts, architecture etc. in each territory, usually one or more in each of the provinces) are non-autonomous peripheral entities, and depended on the central Ministry in Rome for all scientific, organizational economic and financial issues, including personnel. On their own, the national museums and archaeological sites were mere offices of the Superintendencies, often even without a specific Director in charge of their management (Zan 1999; Paolucci 1996).

There is a huge tradition of debate and discussion about the reforms of the whole system, and major museums within them. Many contributions provide an interesting reconstruction over decades (e.g. Bobbio 1993; Cammelli 1996; Mottola Molfino 1998; Petraroia 1998. Also worth noting are the round table on "Reforms and decentralization in reality", on the new journal Aedon on 1998, and the contribution herein by Ainis, Bobbio, Cammelli, and Sciullo).

It is interesting to note how the whole debate refers tacitly to bigger museums and sites (Pompeii, Brera, Uffizi etc.), those that are expected to be able to be self-sufficient; candidates for self-funding given their status and dimension. In other words, there is already a misunderstanding in 
the whole debate - that managerial reforms make sense only when entities are "profitable", or can at least break even. The fact that the British Museum, for example, is well or badly managed, but in any case survives without entrance fees and thus without any potential of breaking even was totally ignored by Italian experts and politicians of the time. More specifically, any notion of accountability and responsibility was completely foreign to the debate prior to 1997.

\section{b) The initial reform of Pompeii (1997)}

The introduction of the new law was supported by a persistent advertising campaign by the Superintendency of Pompeii, which included the publication of the Plan for Pompeii (MIBACT, SAP and WMF, 1997), addressing the need to stop the decay of the site, which would have required ten years and 250 million euros. In parallel to this important document by leading archaeologists, an administrative reform of the Superintendency was carried out. Despite the fact it was advertised as a crucial innovation, a sort of social laboratory on an experimental basis for the whole sector of cultural goods, directly supported by the Vice Prime Minister, the reform of Pompeii is structured very simply in one article of a broader law (Zan 1998/2002; Ferri and Zan 2014). ${ }^{3}$ Some important innovations were introduced, most importantly the idea of an autonomous Superintendency:

1. A Board of Director was set up: rather than relying on the single figure of the Superintendent as had been the case in the past (and still is in many other Superintendencies), the three-member Board created the new position of a "city manager" (in addition to the Superintendent, and the oldest professional in the site). This figure was seen as an empowered financial director: curiously enough, given that accounting and administration are not very sexy labels in Italy, the press and the ministry referred to the position using the English term ("city managers", which normally referred to the general manager of the administration of municipalities, a quite different position). Furthermore, the position could be covered by a temporary contract, which meant hiring people from the private sector. This was the first time that the Ministry opened the door to senior officials not drawn from within the ministerial body and selected by national examinations.

2. A central innovation was that ticket revenue could now be kept by the Pompeii entity. ${ }^{4}$ Before the introduction of the reform, the ticket was a tax collected at the periphery (the Superintendency), then transferred to the centre (the Ministry in Rome), which then allocated

\footnotetext{
${ }^{3}$ Law 352, 8.10.1997, Disposition on cultural goods, art 9, Measures in favor of the archaeological areas of Pompeii. http://www.parlamento.it/parlam/leggi/973521.htm.

${ }^{4}$ The law is incredibly "simple", not defining issues in details. As a field work anecdote, the first time we met the Superintendent of that time, asking him whether he was in the position to change ticket prices, he kindly replied that he would have asked to the Ministerial apparatus.
} 
resources to various peripheral entities according to an internal administrative logic. There was no relation between ticket revenue and eventual allocations. The reform introduced a strong incentive mechanism, and the ticket - now legally redefined as service offset - could be kept at Pompeii to cover costs, including the costs of restoration and conservation. More tickets would mean better opportunities for recovering Pompeii from decay. If the innovation was important in terms of procedure, in substantive terms that also meant a huge increase of resources for Pompeii, from the original 3 million per year allocated by the Ministry to 25 or more million from tickets sales - a big difference!

3. For the first time, a form of accountability was introduced. Pompeii, as an autonomous entity, was required to present a sort of financial report, where all cash transfers were presented and accounted for, revenues as well as expenditures. This solved one of the common problems of Italian public sector museums, that are usually considered simply "non organizations", parts of a higher entity, in this case the Ministry. Also, this provided increased transparency in the use of different revenue sources which heretofore were accounted for individually, but were now included in a single annual report.

But. There was a huge 'but' in the whole 1997 reform. Human resources were not included. The responsibility for human resource management was kept at the Ministry level. Hiring, career progression, firing - all human resource issues - would continue to be managed at the central level, as before. There was an ad hoc national law to define the positions for the whole Ministry, at the centre and in all the peripheral branches, including the newly-autonomous Superintendency of Pompeii. On this critical issue, no innovation was taking place. In substantive terms, this meant that more than a half of the expenditures spent by the Ministry on Pompeii but not managed by the Pompeii autonomous Superintendency would not appear in the Pompeii income statement. If entrance fee allowed for expenditures of $€ 25$ million, the cost of personnel (711 people, for a total of $€ 26$ million as a rough estimate) remained hidden. This is not elegant (certainly when compared to the "one-block grant" solution of the British Museum: Zan 2006): a strange business model, according to which current revenues (tickets) covered extraordinary costs (largely to restore Pompeii after decades of underspending); while current costs (largely labour) were covered by the Ministry.

But much more than making the balance sheet not transparent, this decision hid a very crucial but perverse mechanism in the law. The law meant there was no incentive for reviewing the 
organization of labour (sorely needed in institutions that have been around for centuries). ${ }^{5}$ No way to deal with "make or buy" choices, or for redefining the boundaries of the organization though process of in and outsourcing. For instance, if there were the possibility to provide cleaning through buying a service from the outside rather than using internal employees, this would not be possible. Getting rid of unnecessary labour costs - assuming that one could really do it - would only benefit the financial situation of the Ministry, while any new services would be charged to the Pompeii, consequently reducing resources for conservation. In this sense, the so-called managerial reform of Pompeii was contradictory, unfinished, and "crippled" as it was referred to in jargon. It is easy to predict, if misstaffing causing inability to spend was a major issue at the time, (Zan 1998), that it would continue to be a problem in the future. ${ }^{6}$

It is interesting to introduce here another anecdotal element. A few month after the promulgation of the new law in November 1997, one of the authors of this paper was writing the first analysis on the Pompeii reform (Zan 1998/2002) during a visit at Warwick University, in March/April 1998, following the fieldwork done between November and March. This was really at the early stage of the new regime, with the first "city manager" having just been appointed (March 1998). As is often the case when you do research, when you start writing you piece together the puzzle using the bits of information, documents, interviews etc., until the whole picture starts to take shape. At that stage, the issue of the contradictory, crippled reform emerged. To double check, the author called the Superintendent, who was surprised by this interpretation, and told him to speak with the city manager, who suddenly realized the contradiction in the law, and the need to ask for changes. It would have been simply a matter of three words, to "finish" the reform, and make it consistent with a managerial logic. Despite his efforts, the law was never changed. The 'original sin' - the lack of control of human resources and the organization of labour - is still in place.

Mistakes are possible, certainly, even in lawmaking, and it is hard to believe than someone would be so perfidious as to "plan" such a bad law. Nonetheless, despite the declared "experimental" nature of the law, the intrinsic mistake would never be resolved, and to be honest, with hindsight, one might doubt that anybody inside the Ministry ever even understood the point!

\section{c) Enlarging the reform: the "Museum hubs"}

\footnotetext{
${ }^{5}$ Indeed in substantive terms Pompeii show as presenting an extreme need for solving a problem of mis-staffing: out of 711 employees, only 16 were historians, architects and archeologists, the qualified skills for such a worldwide archaeological site.

${ }^{6}$ The small number of professionals make it hard to manage a huge number of small conservation projects, causing a syndrome of inability to spend.
} 
After Pompeii, five Superintendencies were made autonomous thanks to article 8 of law 368/98: the archaeological Superintendency of Rome (with Ministerial Decree 22 may 2001) and four special Superintendencies for the "Museum Hubs" of Italy's major cultural cities: Venice, Florence, Rome and Naples (established with Ministerial Decree 11 December 2001). The Museum Hubs were special autonomous Superintendencies with functions partially different compared to the sectorial Superintendences (i.e. for archaeology, monuments, artistic goods): they were responsible for the preservation and management of the collections within their museums, but not for the preservation of the heritage (on private or public property) within their territories (as it is for the sectorial Superintendencies). In parallel, law 368/98 established the creation of "Regional Superintendencies", a sort of intermediate coordination, yet without clearly defining their scientific and administrative responsibilities (and the related resources), especially in relationship to the sectorial Superintendencies and Museum Hubs.

The laws establishing the Museum Hubs recalled the Pompeii model both in its most significant innovation (the Board of Directors, the Administrative Director, the financial report and the possibility to retain the ticket income), and its more problematic aspects. Yet, if in the Pompeii experimentation a sort of centralist legacy could still be justified, it is surprising to find the same limits in its further extension. Indeed, notwithstanding wide debate, the autonomy designed for the Museum Hubs did not solve the difficulties encountered at Pompeii: the Museum hubs were still strictly dependent on the Ministry for all personnel issues, including selection, organization, incentives etc. $^{7}$

The analysis of the implementation of this mitigated autonomy conducted by one of the authors in the Venetian Museum Hub draws attention to this and other relevant issues (Bonini Baraldi 2007, 2014). Since its very transformation from "Historical, artistic, and demo-ethnoanthropologic Superintendency of Venice" (the territorial sectorial Superintendency) to the "Venetian Museum Hub", what immediately emerged was the need for new skills, both in quantitative and qualitative terms. This was clear, given that the management of museums, compared to the preservation of the territorial heritage, brings with it unprecedented duties (such as the calculations of the museums guards salaries and corollary incentives). ${ }^{8}$ The "Museum Hub" project was ambitious in itself, calling for new curatorial (for the artistic direction of the museums) and managerial skills (for the financial reporting and the new accounting system). Yet, due to the

\footnotetext{
${ }^{7}$ Gherpelli himself (the first city manager of Pompeii), declared that "the autonomy conceived for Pompeii has a clear instrumental meaning: it is a tool to obtain testable and theoretically extensible results" (Gherpelli 1999: 1), and underlined the need to "eliminate as soon as possible the limits already visible in the law, which suffers of too many compromises. The law can be modified, we believe that it should" (Gherpelli 1999: 7).

${ }^{8}$ Five Museums were under responsibility of the Venetian Museum Hub: Galleria dell'Accademia, Galleria Giorgio Franchetti, Museo d'Arte Orientale della Cà D'Orro and Museo di Palazzo Grimani.
} 
lack of autonomy on personnel and the block on ministerial hiring, the Venetian Museums Hub organizational chart remained unmodified (apart from the relevant, but by no means sufficient, figure of the Administrative Director). ${ }^{9}$ This is probably why in the strategic document requested by the Superintendent for its constitution, the "management form" (a compulsory field within the document) was analysed in less than six lines, while all aspects related to institutional assets, organization, coordination, control, and accountability were completely neglected. Furthermore, in its transformation the Museum Hub had to give up some of its employees to the recently created Regional Superintendency and to the Superintendency for the architectonic, environmental, artistic and demo-ethno-anthropologic heritage of Venice and the Lagoon (a newly born Superintendency created through the merging of two previous sectorial Superintendencies - which had inherited from the Museum Hub the conservation function of the territory) leading to an additional drainage of personnel.

The nomination of the Administrative Director itself encountered several obstacles, preventing for several months the creation of the Administrative Board and, consequently, the startup of the Museum Hub's autonomy as a whole. Indeed, at its creation (11 December 2001), the Venetian Museums Hub did not have anyone on its staff who actually could apply for the position. ${ }^{10}$ At the same time, nobody applied for the post through the ministerial national exam: as the Museums Hub Superintendent stated "to compete for this position one should have a university Master's degree. Once obtained, it will have very high responsibilities and very low pay: no one would apply for a position like this" (Interview with the Museum Hub Superintendent, 16 September 2003). The impasse was only solved after a year and a half, with the voluntary transfer of a civil servant (an archaeologist) from another national office. In the meanwhile, autonomy was stalled, and the Museum Hub lived in a sort of "administrative limbo".

Relevant issues regarding financial and accounting autonomy also emerged, with important consequences at the operational level. More than one year after the Museum Hubs' creation, the Ministry finally issued the Regulation for their accounting and financial operations (without which the autonomous management could not function). The Regulation (DPR 240 of 2003) established the procedures whereby the Museum Hub could include ticket income in the financial report. Yet, due to an oversight, this possibility was not included in the first approved version of the Urbani Code (d.lgs. 22/01/2004, $\mathrm{N}^{\circ} 42$ ), which remained unmodified until 2006. ${ }^{11}$ The problem was that

\footnotetext{
${ }^{9}$ Document on personnel endowment (Internal Document, Venetian Museums Hub, 2003)

10 "The most qualified official we have in the administrative staff doesn't even have a university decree" (Interview to the Venetian Museum Hub Superintendent, 16 September 2013).

${ }^{11}$ Based on art. 10 of this law, all earned income of national museums and sites must flow into the State financial report, in order to be reallocated later on to each administration with Decree of the Ministry of Finance.
} 
the Code has greater legal force than the Regulation, effectively making the possibility to retain the income from tickets illegal. Since the Auditors of the Superintendency could not approve a financial statement which included the earned income, the management of the Museum Hubs has remained blocked for a long time (Bonini Baraldi 2007). Furthermore, for the year 2004, the Museums Hubs could benefit from state funding only on loan and, according to the law, $30 \%$ of the earned income could still be taken by the State and subsequently re-allocated among its administrations. Here again, reforms seem to exacerbate rather than reduce the extreme uncertainty of financial resources that characterizes many Italian public administrations.

But the most incoherent aspect of the entire process lay in the apparent will - declared by central leaders and politicians in the months of April-September 2003 - to suppress the newlyestablished and not yet functioning Museum Hubs, and to change their institutional and managerial form. Although just established through the law 368/98, the Museum Hubs did not appear in the very first draft of the Urbani Code which, for the management of most important national museums, required the creation of public-private foundations. ${ }^{12}$ In October 2003 the "danger" seems to have finally passed: with the final drafting of the Urban Code (22/01/2004) the Museum Hubs continued to exist. The reasons for such a change were not very clear (almost nothing appeared in the specialist press) but it seems that a significant role was played by the Unions, to protect the ministerial staff (interview Director of Galleria Franchetti, 24 September 2003).

To sum up, within less than five years the law for autonomy was experimented with in Pompeii (1997) and extended to the Museum Hubs (1998); the Museums Hubs were created with special ministerial decree (2001); the relative Regulation for the Accounting and Financial operation was issued (May 2003); and even before the Hubs could start working (appointing the administrative director, setting up the Board of Directors, issuing the first financial report etc.), it was seriously thought, with proper draft law, to suppress them and transfer their functions to newly created foundations (August-October 2003).

In general, the first years of mitigated autonomy in the Museum Hubs were very difficult and contradictory: what emerges is a partial autonomy, characterised both by the intrinsic limits of the instruments introduced (and already evident in the experiment of Pompeii); the enormous difficulties in its implementation; and an ambiguous political "strategy". In the meantime, the Museums Hubs remained stuck in an ambitious project without personnel, resources and future. According to a quick update with the Venetian Museum Hub, the following years have not been better: as the Administrative Director affirms (14 January 2007) "unfortunately not much has changed. Human resources remain the biggest problem. With fewer and fewer people, managed for

${ }^{12}$ Article 6, comma 4, of d.lgs. 22/01/2004, $\mathrm{N}^{\circ} 42$ first draft (never issued). 
the most part centrally, without incentives and therefore demotivated, is really difficult to follow the road of autonomy, which becomes a daily battle".

\section{d) The tacit dismantlement of the Pompeii reform innovations}

Bad things can get worse. This is a short summary of what happened to the Pompeii reform after its introduction: the dismantlement/removal of a crippled reform (on these aspects see extensively Ferry and Zan 2014, forthcoming). In updating the initial research ten years after the introduction of the reform, a sort of social equation ironically emerges (Ferri and Zan 2014: 381): "Pompeii $2008=$ 1997 Reform - City Manager - €70 million + Naples + Commissario" (we are changing the order of factors here to follow the presentation as in point $3 . \mathrm{b}$ above). Numerous new events and interventions had a negative impact on the already contradictory reform.

- First, the position of city manager gave rise to a form of political clientele in appointing the second and third person. The second was a retired General (think in terms of skills and knowledge management needed for such a historical site!), the third was an archaeologist (with the result that all the three members of the board had a similar professional background, instead of combining different viewpoints and bringing in a more managerial viewpoint, as had been the intention of the law). Eventually, and almost silently, the position was abolished in 2007, without any justification by the Ministry. A core part of the whole reform simply disappeared. None of the City Managers, in any case, felt the need to present a report on their mandate (as no doubt, no procedure required them to do so).

- Second, the revenues were not left totally to the site forever. Soon $30 \%$ was appropriated annually by the Ministry (since 2006), in order to better subsidize the financial needs of other sites and museums. This was a second attack on the core of the reform, showing a total disregard for the logic of responsibility that underlined the reform (albeit not totally consistently). Moreover, on two occasions the Ministry took away part of the savings of the site - cash amounts that were left temporarily due to a persistent inability to spend them - and used them for other sites ( $€ 30$ million in 2006 and $€ 40$ million in 2008). That was the third attack: taking resources away from the site, despite the logic of autonomous management. At this point, it is not clear who can be considered responsible for what. After ten years, and receiving the funding, was the recovery of Pompeii - called for by the Plan for Pompeii in 1997, and the call for $€ 250$ million Euro over a period of 10 years - reached or not? Who was responsible, given the distortion of part of the "agreed upon" resources? In any case, nobody ever had to write a report related to the plan for Pompeii to answer any of these questions! 
- Third, in 2008 the Superintendence of Pompeii was merged with that of Naples, which was in very poor financial shape, with the result that the tickets for Pompeii were funding the desperate lack of funds of in Naples, rather than the site itself, once again calling into question the entire system of responsibility and accountability that was foreseen by the law.

- Last but not least, in July 2008 the autonomy was suspended, centralizing it directly under a Commissioner that who directly reported to the Prime Ministry, replacing the Board of Directors, within a sort of client/patron relationship. ${ }^{13}$ After a few months, in February 2009, the first commissioner was fired without any public explanation, and a second one was appointed. One year later, in June 2010 the Court of Accounts (Corte dei Conti, 2010) declared that this extraordinary administration was illegal, so the situation went back to its starting point, back to what was left of the reform.

The whole sense of the (already crippled) reform from a management point of view was seriously threatened. From a substantive point of view, it is interesting to notice that serious problems of the inability to spend were still in place. When a generous amount of money was provided in conjunction with the European Community (Franceschini, 2015) for a radical attempt to solve Pompeii's decay, there was a serious risk that money would have to be given back because of the inability to spend the $€ 105$ million within the mandatory 3 years of the grant (Osser 2014; Fantuzzi and Sironi 2015). Only the generosity of the funders, who accepted an extension of the period, prevented this from taking place. Therefore, despite the reform, and its dismantling in different forms, the commissario etc. many bad things did not change at all.

\section{e) The Franceschini reform}

More recently, some important innovations have been introduced by the so-called "Franceschini reform" (in the name of the Minister in charge from 2014 to 2018), following some previous changes. ${ }^{14}$ By its nature, the system of Superintendencies - the local branches of the Ministry - was coupling responsibilities of protection of national heritage with direct involvement in the running of national museums and sites. In a sense separating these two main aspects, the reform aimed at

\footnotetext{
${ }^{13}$ It is impossible to translate the term "Commissario" in English, given the different administrative traditions. This is a sort of extraordinary administration, often used in case of natural disaster to coordinate intervention in emergency case. During the last two decades, this has been overused in many situations, including the art sector (e.g. Opera houses). See Ferri (2016) for a deeper discussion on the whole experience, and Ferri \& Zan (forthcoming) for a more systematic analysis of patronage relations in extraordinary administrations.

${ }^{14}$ See d.1. 31/05/2014 n.83; d.p.c.m 29/08/2014 n.171; D.M. 27/11/2014; DM 23/12/2014; D.M. 43 23/01/2016, D.M. 44 23/.01/2016, D.M. 113 23/02/2018.
} 
reorganizing both the central and peripheral administration of the Ministry of Culture and Tourism, and creating a national museum system.

At the peripheral level, the reform changed the role of the Superintendencies, while establishing new entities: autonomous museums, regional museum hubs and regional secretariats (ministerial decree n. 44 23/01/2016). Superintendencies are now responsible only for the protection of cultural heritage but not for its management and enhancement, as it was in the past. ${ }^{15}$ In parallel, the new national museum system was structured into two main groups. A first group is composed of thirty so-called "autonomous museums" (twenty museums as of 2014 and a further ten as of 2016), in charge of the management and enhancement of their own heritage and collections (only the most important museums of the country are included in this list). A second group is made up of seventeen "regional museum hubs", in charge of all national non-autonomous museums and heritage sites in their region, plus all other public or private museums, through ad hoc agreements. ${ }^{16}$ Regional secretariats replaced regional directorates, with the aim to coordinate territorial Superintendencies and to cooperate with local authorities and other institutions in the region.

In a sense, this reform explicitly attempted to solve the most critical issues in the museum system providing the conditions for more effective management: it required the adoption of a set of minimum museum standards; it underlined the need for specific professional profiles, and defined the functions to be performed within each museum (direction/management; collections care and management, study, research and educational activities; marketing, fund raising, services to the public and PR; administration, finance and HRM; structures, exhibits and security: DM 23/12/2014). ${ }^{17}$ In addition, each museum (autonomous or part of the regional museum hub) should have its own statute, charter of services, and budget. ${ }^{18}$ The thirty most important museums gained

\footnotetext{
${ }^{15}$ Other important changes are introduced for the superintendence system: Superintendencies for archaeology and Superintendencies for fine arts and landscape merged, becoming a unique Superintendency for archaeology, fine arts and landscape (thirty-nine in the country). Archival Superintendencies were merged with library heritage. This part of the reform gave raise to very radical controversies by heritage professionals, according to which the reform of superintendence would threaten their professional values and the traditional protection function of this peripheral body, by splitting it up from the heritage management and enhancement (Montanari, 2016; Guzzo, 2018). In January 2018, 70 of the most critical and renowned professionals signed an open letter to condemn the critical situation "Imbavagliati soprintendenti e direttori, denunciamo noi il caos dei beni culturali" (available at :

https://emergenzacultura.org/2018/01/19/imbavagliati-soprintendenti-e-direttori-denunciamo-noi-il-caos-nei-beniculturali/).

${ }^{16}$ Note the completely new meaning of the term "museum hub" in the new reform, compared to what described above in section 4.c. The regional museum hubs aim at ensuring "the enjoyment and enhancement of cultural sites (...) by defining common enhancement strategies and goals, in relation to the territory within its jurisdiction" (DPCM 171, 29 August 2014 ).

${ }^{17}$ DM n.113 23/02/2018, states that "the presence of specific professional profiles (...) constitutes an essential requirement to ensure the adequate management of a museum and the capacity to design an effective cultural project (...). We refer to the director, the responsible for: the educational services; the administrative and economic-financial procedures; the public relations, marketing and fund raising; the staff for reception and surveillance".

${ }^{18}$ Interesting enough, the latter involves the introduction in May 2017 of an integrated economic report (REIRendiconto Economico Integrato), elaborated in collaboration with the BCG-Boston Consulting Group and Civicum
} 
the status of executive offices ("ufficio dirigenziale"), benefitting from a "scientific, financial, accounting and organizational autonomy" (DM 44 23/12/2014). Their Directors were selected through international open competitions, and are supported by a board of trustees, a scientific committee and a college of auditors.

Despite the positive attempts, many weaknesses were immediately pointed out, raising controversies both among professionals and in the press. The Italian section of ICOM expressed some doubts about the envisioned functional structure (i.e. the inclusion of educational activities in the second group of functions and of marketing and fundraising in the third one). Other doubts were raised regarding the unclear distinction between governance and management bodies, since the Board of Trustees is ex ufficio chaired by the museum director himself (which means the controlled is at the same time the controller: Jallà 2015). A louder controversy emerged in the press related to the selection of the twenty (later thirty) museums directors: at the beginning because of the unusual results (only one of the directors was drawn from the Ministry apparatus, seven of them were foreigners and four of them were Italians working abroad: MIBACT 2015), later on, the inconsistency of the legal norms emerged at the Regional Administrative Court regarding the impossibility for the Ministry to hire foreign museum directors not in possession of the Italian citizenship (TAR, Tribunale Amministrativo Regionale).${ }^{19}$ In our opinion however, none of these debates really tackled the heart of the problem: the inability of the reform to address the neverending problem of human resources. Actually, the notion of autonomy used in the reform is purely juridical, and extremely misleading when translating it in the vocabulary of international management studies. Following the tradition from Pompeii's reform onward, the new directors do not have any decision-making power with regards selection and hiring/firing/managing human resources within their organization. At most they can make proposals about staffing (Forte, 2015), but the related regulation has not been changed and still depends on ministerial norms and decrees.

To make the situation even more bizarre, a further event related to human resource issues took place in May 2016 (Official Journal 4 , Open competition special series, n.41, 24 May 2016), when an open competition to hire 500 new senior staff for the whole ministerial apparatus was launched (the first after decades of a hiring freeze). ${ }^{20}$ Curiously enough, the call completely ignored skills and profiles related to the functions established by the reform itself, and did not include any

\footnotetext{
Association on an experimental base. The Report was first experimented in 5 ministerial structures -3 autonomous museums and 3 regional museum hubs, for a total amount of 26 entities.

${ }^{19}$ On this matter, the Regional Administrative Court has already rendered 16 decisions and the State Council other 6 , but the final decision has not yet been taken.

${ }^{20}$ It has been noticed that when the reform was launched the average age of ministerial personnel was 55 years old (Casini, 2017).
} 
managerial position. ${ }^{21}$ Since the Ministry itself acknowledged these skills as crucial for effective museum management, it is hard to accept this as simply administrative naiveté. We believe the omission is much worse: for the profile "promotion and communication", any background was considered acceptable, and postgraduate training was required in the promotion of cultural policies, economy of art and culture, management of cultural heritage and/or communication, or 36 months of professional experience, as if policy-management-communication skills were interchangeable. Not surprisingly, what emerges from a quick review of the selected candidates is that the humanistic, artistic-historical profile still prevails. Moreover, some of the candidates for the "promotion and communication" profile took part in the same competition for different posts, for instance as art historians or archaeologists. This might hide the fact that the "promotion and communication officer" profile is still considered a second-best choice.

In addition to this, the special role of ALES spa has to be pointed out. ALES spa is an inhouse company of the Ministry, founded in 1997, and from 2016 incorporating also ARCUS spa (another ministerial company), whose role is to support the Ministry of Culture in a variety of functions, such as management and enhancement of cultural heritage, administrative and legal tasks etc. One possible answer for the omission of administrative and managerial profiles in the call for new staff could lie in the fact that, for the moment, the Ministry "prefers" such tasks to be externalised and carried out by ALES staff, to whom it resorts at both at the central and peripheral level. In this regard, some criticism has emerged, also by using ALES the Ministry appears to bypass some administrative and financial constraints. ${ }^{22}$ ALES was in fact also subject of a parliamentary investigation. ${ }^{23}$

Relevant problems also emerged with regards to the new peripheral organizational structure, for instance the hierarchical relationships between the new roles of regional secretary, regional museum hub director and autonomous museum director (Cammelli 2016; Cammelli, Piperata, Sciullo, Sau 2016) and the relative distribution of personnel (OECD 2016).

In short, despite some encouraging results in terms of museum visitors ( $+31 \%$ from 2013 to 2017) which may be due to external factors such as increased tourism to Italy, and improved financial performance ( $+53 \%$ in income from 2013 to 2017) which could be attributed to changing ticketing policy, the crucial issue of human resources was once again neglected by the Franceschini

\footnotetext{
${ }^{21}$ The following post were established: architect (130 posts), archivist (95 posts), archaeologist (90 posts), restorer (80 posts), librarian (25 posts), demo-ethno anthropologist (sic!) (5 posts), anthropologist (5 posts), art historian (40 posts) and promotion and communication officer (30 posts).

${ }^{22}$ According to a press release (12.07.2017) of the union federation for cultural heritage CONF-SAL UNSA, almost $60 \%$ of the staff of the general directorates are made up of ALES personnel, carrying out ordinary tasks rather than support ones.

${ }^{23}$ Atto n. 3-03354, pubblicato in data 20 dicembre 2016, seduta $n .735$.
} 
reform, and the 'original sin' still in place. It could be argued that the problem was already present earlier in the process: designing a reform, planning its organizational implications and providing the adequate instruments for its implementation is after all a matter of human resources. Radically put, the issue of human resource management requires forms of knowledge that relate not merely to (Italian) legislation, but above all, to the knowledge developed internationally within the field of management studies. In this sense, the Franceschini reform confirmed once again the dominance of the legislative discourse in the Italian context (Cassese 1999; Panozzo 2000; Zan 2006; Bonini Baraldi 2014).

\section{Concluding remarks for a policy/research agenda}

The reconstruction of the lack of understanding of human resource management in the whole debate about the reform of national heritage entities (as seen from the "genealogy" of reform, from Pompeii to the Franceschini reform, which show astonishing degrees of "internal consistency") provides a picture that could be summarized in the following terms:

- the dominance of legal approach and an abnormal role played by law making;

- the radical lack of understanding by Italian law makers of any notion of management, even public sector management, as developed internationally, and its basic issue of autonomy (as defined in the management vocabulary), accountability, responsibility and similar best practices;

- the inaccuracy of law making, with several "mistakes" made during the process (from the initial forgetting of human resources in the Pompeii law, to the bizarre case of museum hubs and the inconsistencies with the first version of the Urbani code);

- the inherent 'laziness' of law making: Pompeii was presented as an experiment - twenty years later the main internal inconsistencies of the law have still not been solved.

If these elements explain many problems of the Italian public sector transformation, when considering human resources another element enters into play, possibly worsening the situation: the protectionist approach to public employment, in which the dominance of the legislative process creates a fertile ground. The issue of human resource management is simply ignored in the legislative reforms, as if it were a secondary issue. Behind this omission, however, there is much more than simple inattention: there is a clear will to avoid touching longstanding vested interests. A neo-liberal view is far from our position, yet without approaching, debating and finding sustainable solutions for human resource and organizational issues, any reform of the heritage system will be largely meaningless. 
The reconstruction of events and the interpretation of this paper aims at addressing some crucial questions for the future, both for a policy making and a research agenda. Is decentralization seriously to be taken into account, and if so, how it will incorporate the issue of human resource management? Is responsibility a notion that will be fully acknowledged in the process of administrative transformation or not? And what about achieving consistent forms of accountability? Unless these questions are addressed with honesty, courage and intelligence, the risk is that future reforms will continue to share the flaws of those in the past, and, as a consequence, be doomed to failure in the medium-to-long term.

\section{Bibliography}

Ainis, M. 1998. "Il decentramento possibile", Tavola rotonda su Riforme e decentramento alla prova dei fatti: i beni e le attività culturali nel d.lg. 112/. Aedon, no.1.

Barzelay, M. 1992. Breaking Through Bureaucracy: A New Vision for Managing in Government. Berkeley: University of California Press.

Bobbio, L. 1998. "Due scenari per il decentramento dei musei", Tavola rotonda su Riforme e decentramento alla prova dei fatti: i beni e le attività culturali nel d.lg. 112/, Aedon, no. 1.

Bobbio, L. 1993. "Le peculiarità dell'ordinamento museale italiano nel contesto europeo e il dibattito sulla riforma" ["The Peculiarities of the Italian Museum System in the European Context and the Debate on the Reform"]. In L'immagine e la memoria: indagine sulla struttura del museo in Italia e nel mondo, edited by Pietro Antonio Valentino, 41-63. Milan: Civita, Leonardo Periodici.

Bonini Baraldi, S. 2014. "Evaluating Results of Public Sector Reforms in Rechtsstaat Countries: The Role of Context and the Role of Processes in the Reform of the Italian and French Cultural Heritage System”. International Public Management Journal, 17 (3): 411-432.

Bonini Baraldi, S. 2007. Management, Beni Culturali e Pubblica Amministrazione [Management, Cultural Heritage and Public Administration]. Milan: Franco Angeli.

Cammelli, M. 1998. "Il decentramento difficile", Tavola rotonda su Riforme e decentramento alla prova dei fatti: i beni e le attività culturali nel d.lg. 112/1998. Aedon, no. 1.

Cammelli, M. 1996. "Riordino istituzionale dei beni culturali e dello spettacolo in una prospettiva federalista". Economia della Cultura, 3: 198-226.

Cammelli, M. 2016. "L'avvio della riforma del MIBACT: echi dalla periferia". Aedon, no. 1.

Cammelli, M., G. Piperata, G. Sciullo, A. Sau. 2016. "La riorganizzazione del Mibact alla prova dei fatti: l'amministrazione periferica. Nota della Direzione della Rivista (4 aprile 2016)", Aedon, no. 1.

Casini, L. 2017. “"Learning by experience"? La riforma del ministero dei Beni e delle Attività culturali e del Turismo". Aedon, no. 3.

Cassese, S. 1998. "La semplificazione amministrativa e l'orologio di Taylor", Rivista trimestrale di diritto pubblico, 3: 699 ss.

Cassese, S. 1999. "I caratteri originali della storia amministrativa italiana". Le Carte e la Storia. Rivista di storia delle istituzioni, 1: 7-15.

Corte dei Conti, Deliberazione n. 16/2010/P. Corte dei Conti; August 4, 2010. Accessed 28 May 2018.

http://www.corteconti.it/export/sites/portalecdc/_documenti/controllo/sez_legittimita/2010/ delibera_16_2010_p.pdf

D’Alessio, G. 1992. "I Musei Italiani tra Normativa Statale e Legislazione Nazionale" ["Italian Museums Between State and Regional Law"]. In L'immagine e la memoria: indagine sulla 
struttura del museo in Italia e nel mondo, edited by Pietro Antonio Valentino, 65-97.

Milan: Civita, Leonardo Periodici.

Dell'Orso, S. 2002, Altro che musei. La questione dei beni culturali in Italia, Roma-Napoli: Laterza Fantauzzi, P., Sironi F. 2015. "Chi blocca la rinascita di Pompei”, L'Espresso, 4 marzo.

Ferri P., and L. Zan. (forthcoming), "Accountability and Patronage in Extraordinary Administrations: Evidence from Pompeii". Financial Management and Accountability.

Ferri P., and L. Zan. 2014. "Ten Years After. The Rise and Fall of Autonomy in Pompeii". Critical Perspectives in Accounting, 25: 368-387.

Forte, P. 2015. "I nuovi musei statali: un primo passo nella giusta direzione". Aedon, no.1.

Franceschini D. 2015. Relazione sullo stato di avanzamento dei lavori e su eventuali aggiornamenti del cronoprogramma del Grande Progetto Pompei (aggiornata al 31.12.2014)", Camera dei Deputati, Doc. CCXX n. 2, 2015. Accessed 28 May 2018.

http://www.camera.it/leg 17/491?idLegislatura=17\&categoria=220\&tipologiaDoc=docume nto\&numero $=002 \&$ doc $=$ pdfel

Gherpelli, G. 1999. "L'autonomia pilota: l'esperienza di Pompei”. Aedon, no.1.

Guzzo, P. G. 2018. “Tutela e valorizzazione: unite o separate?”. Accessed 28 May 2018. http://www.patrimoniosos.it/rsol.php?op=getintervento\&id=1225.

Hood, C. 1991. “A Public Management for all Seasons?”. Public Administration, 69: 3-19.

Hood, C. 1995a. "Emerging Issues in Public Administration". Public Administration, 73: 165-183.

Hood, C.1995b. "The New Public Management in the 80s: Variations on a Theme". Accounting Organizations and Society, 20(2-3): 93-110.

Jalla, D. L. 2015. "La riforma dei musei statali”. Il Giornale delle Fondazioni. Accessed 16 May 2018.

http://www.ilgiornaledellefondazioni.com/content/la-riforma-dei-musei-statali-italiani

Kickert, W. J. M. 1997. "Public Governance in the Netherlands: An Alternative to Anglo-American Managerialism". Public Administration, 75(4): 731-752.

Kickert, W. J. M. 2004. "Distinctiveness in the Study of Public Management in Europe: A Historical-Institutional Analysis of France, Germany and Italy". Accessed 28 May 2018. https://repub.eur.nl/pub/1792/

Ministero per i Beni Culturali e Ambientali, Soprintendenza Archeologica di Pompei, and World Monuments Fund. 1997. Un Piano per Pompei. Piano programma per la conservazione e la gestione del patrimonio storico-archeologico della città antica.

Ministero per i Beni e le Attività Culturali e il Turismo. 2015. Selezione pubblica per i direttori dei musei italiani. Franceschini: si volta pagina, direttori da tutto il mondo. Accessed 28 May 2018. http://www.beniculturali.it/mibac/export/MiBAC/sito-

MiBAC/Contenuti/visualizza_asset.html_1785022305.html.

Montanari, T. 2016. "Ministero dei disastri culturali. Lettera aperta al ministro Franceschini". Micromega, no. 4.

Mottola Molfino, A. 1998. "Musei: né con lo Stato né con le Regioni”. Il Giornale dell'Arte, no. 165, April, 93.

OECD, Organization for Economic Cooperation and Development, LEED, Ministero per i Beni e le attività Culturali ed il Turismo. 2016. "ACTORS Italia - Attrattori Culturali Per il Turismo e l'Occupazione - Review Reggio Calabria”. Accessed 28 May 2018. http://www.oecd.org/cfe/leed/I1_Review_report_Reggio_Calabria.pdf

Osser, E. 2014. "Pompei, che fatica! Ma forse ce la fa". Il Giornale dell'Arte, no. 347, November.

Panozzo, F. 2000. "Management by Decree: Paradoxes in the Reform of the Italian Public Sector". Scandinavian Journal of Management, 16: 357-373.

Paolucci, A. 1996. "Italia, Paese del Museo Diffuso" ["Italy, a Widespread Museum Country"]. In La Gestione dei Musei Civici: Pubblico o Privato?, edited by Cristiana Morigi Govi and Alessandra Mottola Molfino, 33-45. Torino: Allemandi.

Petraroia, P. 1998. "Un patrimonio di ambiguità". Il Sole 24 ore, 22 February. 
Pollitt, C. and G. Bouckaert. 2011. Public Management Reform: A Comparative Analysis New Public Management, Governance and the Neo-Weberian State. Oxford: Oxford University Press.

Sciullo G. 1998. "Beni culturali e principio di delega, Tavola rotonda su Riforme e decentramento alla prova dei fatti: i beni e le attività culturali nel d.lg. 112/, 1998, Aedon, no.1.

Sicca, L.M., and L. Zan. 2005. "Much Ado About management". International Journal of Art Management, 7(3): 46-64.

Zan, L. 2002. "Renewing Pompeii, Year Zero. Promises and Expectations from New Approaches to Museum Management and Accountability". Critical Perspectives in Accounting, 13: 89137. Original published in Italian: Zan, L. 1998. "Rilanciare Pompei: anno zero. Le attese verso approcci manageriali e forme moderne di accountability". Rivista di Studi Pompeiani, 9: 7-39.

Zan, L. 2006. Managerial Rhetoric and Arts Organizations. Hampshire and New York: PalgraveMacmillan.

Zan, L. 1999. Conservazione e Innovazione Nei Musei Italiani: Management e Processi di Cambiamento [Conservation and Innovation in Italian Museums: Management and Change Processes]. Milan: Etas. 